I use the Delta pump [3], an open loop insulin delivery system which utilizes $\mathrm{U}-100$ regular insulin contained in a reservoir and propelled forward through the tubing by the repetitive action of a solenoid plunger pinching the area of tubing located between two check valves. The reservoir is usually refilled every 3-7 days depending on the patient's daily insulin requirement. Since the aggregation of insulin solutions had been described in implanted devices maintained at body temperature, I was surprised to meet this problem in the Delta open-loop pump. The precipitation seemed to start in either the tubing near the needle and/or in the tubing between the check values. Since the tubing adjacent to the subcutaneously placed needle is pressed against the skin, aggregation here is consistent with the association of this problem with higher temperatures [4]. The insulin contained in the area between the valves is subjected to the repetitive action of the solenoid plunger. Aggregation here is consistent with the association of this problem with agitation of the insulin solution [4].

To circumvent this problem, I initially dissolved glutamic acid $(50 \mathrm{mg} / 10 \mathrm{ml}$ vial) into the insulin under sterile conditions [5]. Although this prevented the aggregation, dissolving the dicarboxylic amino acid was difficult and some patients complained of burning at the needle site, especially during the administration of the preprandial bolus. After publication of reference 2, I used a physiological concentration of $\mathrm{NaHCO}_{3}(26 \mathrm{mmol} / \mathrm{l})$ to achieve the same end. To obtain this concentration, which is equivalent to $0.26 \mathrm{mmol} / 10 \mathrm{ml}$ vial, $0.3 \mathrm{ml}$ of the commercially available (at least in the USA) bicarbonate solution $(44.5 \mathrm{mmol} / 50 \mathrm{ml})$ is added under sterile conditions to a $10 \mathrm{ml}$ vial of $\mathrm{U}-100$ regular insulin. The addition of bicarbonate has been successful in preventing aggregation of the insulin solutions in the eight patients in whom this method has been used. The first patient was started nearly one year ago. Since aggregation seems to occur more readily when flow rates are low, it is particularly gratifying that this approach has been successful in a patient receiving $0.003 \mathrm{ml} / \mathrm{h}(0.3 \mathrm{U} / \mathrm{h})$.

Insulin aggregation has not been reported to be a problem with other open-loop insulin delivery systems (Mill-Hill and Autosy- ringe), probably because they use less concentrated insulin solutions. However, Autosyringe have modified their device so that now U-100 insulin can be utilized. If insulin aggregation becomes a problem in the tubing near the patient's body, the addition of physiological concentrations of $\mathrm{NaHCO}_{3}$ should be helpful.

Yours sincerely,

M. B. Davidson

\section{References}

1. James DE, Jenkins AG, Kreagen EW, Chisholm DJ (1981) Insulin precipitation in artificial infusion devices. Diabetologia 21: 554-557

2. Lougheed WD, Fischer U, Perlman K, Albisser AM (1981) A physiological solvent for crystalline insulin. Diabetologia 20 : 51-53

3. Siposs GG, Davidson MB (1981) A new open-loop insulin delivery system. Med Instrum (Baltimore) $15: 338-340$

4. Lougheed WD, Woulfe-Flanagan H, Clement JR, Albisser AM (1980) Insulin aggregation in artificial delivery systems. Diabetologia 19:1-9

5. Bringer J, Heldt A, Grodsky GM (1981) Prevention of insulin aggregation by dicarboxylic acids during prolonged infusion. Diabetes 30:83-85

M. B. Davidson, M.D.

Diabetes Program

Cedars-Sinai Medical Center

870 Beverly Boulevard

Los Angeles

California 90048, USA

\title{
Aspects of Non-Enzymatic Glycosylation of Serum Proteins in Relation to Different Glucose Loads
}

DearSir,

Svendsen et al. [1] and Bolli et al. [2], respectively, have shown rapid changes in the concentration of total stable and unstable glycosylated haemoglobin $\mathrm{A}_{1 \mathrm{c}}\left(\mathrm{HbA}_{1 \mathrm{c}}\right)$ and $\mathrm{HbA}_{1}$ to be dependent on short-term fluctuations in blood glucose levels. This phenomenon is regarded as representing the formation and dissociation of unstable $\mathrm{HbA}_{1}$ (aldimine-linked adduct), which is correlated with significant increases or reductions in glycaemic values.

Recently, non-enzymatic glycosylation of total serum proteins has also been shown to be increased in diabetic patients [3-5]. However, it has not been proven whether rapid changes in glucose levels in vivo and in vitro affect the level of glycosylated serum proteins [5]. We have therefore measured glycosylated serum proteins in ten normal subjects (aged $40 \pm 10$ years; mean \pm SD) and in 12 Type 1 (insulin-dependent) diabetic patients (aged $38 \pm 9$ years) after an overnight fast during an oral glucose tolerance test and several days later during a continous $5 \mathrm{~h} \mathrm{IV}$ infusion of glucose $(0.33 \mathrm{~g} / \mathrm{kg}$ body weight in a bolus $+0.9 \mathrm{~g} / \mathrm{min}$ in normal subjects and $0.6 \mathrm{~g} / \mathrm{min}$ in diabetic patients). Glycosylated serum proteins levels were determined by thiobarbituric acid reaction before and after dialysis of serum samples against $0.15 \mathrm{~mol} / 1$ saline solution $(1: 350)$ at $4{ }^{\circ} \mathrm{C}$ for $18 \mathrm{~h}$ (3). In the diabetic patients, the fasting glucose levels were higher $(8.1 \pm 3.1 \mathrm{mmol} / \mathrm{l})$ than in the normal subjects $(4.3 \pm$ $0.3 \mathrm{mmol} / \mathrm{l})$. Before dialysis, glycosylated serum proteins, expressed as nmol 5-hydroxymethylfurfural (5-HMF)/mg protein, showed values which were in parallel with the glycaemic values observed before and during the glucose loads. After dialysis, glucose was always $<0.2 \mathrm{mmol} / \mathrm{l}$ in samples from both groups, while 5HMF gave values lower than those observed before removal of glucose $(p<0.001)$. The mean fall was proportionate to glycaemic levels $(p<0.001)$. However, in every assay, diabetic patients showed higher 5-HMF values than normal subjects ( $p<0.001$, Table 1$)$. Moreover, after dialysis, 5-HMF levels were not significantly increased after different glucose loads. In normal and diabetic subjects, they ranged between 0.51 and 0.53 and between 0.93 and $0.97 \mathrm{nmol} 5-\mathrm{HMF} / \mathrm{mg}$ protein, respectively, during the oral glucose tolerance test with similar values during IV glucose infusion.

In agreement with the findings in vitro of Kennedy et al. [4], our observations in vivo indicate that the determination of glycosylated serum protein levels is influenced by free glucose present in the sample. However, as the oxalic acid used in the thiobarbituric acid reaction test induces rearrangement of the Schiff base [6], it cannot be excluded that the decreases in 5-HMF found after dialysis could 
Table 1. Mean values of 5-HMF (nmol/mg protein) observed during different glucose loads, before and after dialysis of serum samples

\begin{tabular}{|c|c|c|c|c|c|c|c|c|c|}
\hline & \multicolumn{3}{|c|}{ Oral glucose tolerance test } & \multicolumn{6}{|c|}{ Intravenous glucose infusion } \\
\hline & \multicolumn{3}{|l|}{ Time (min) } & \multicolumn{6}{|l|}{ Time (min) } \\
\hline & 0 & 60 & 180 & 0 & 5 & 30 & 120 & 240 & 300 \\
\hline \multicolumn{10}{|l|}{ Normal subjects } \\
\hline $\begin{array}{l}\text { Blood glucose } \\
(\mathrm{mmol} / 1)\end{array}$ & 4.30 & 7.70 & 5.00 & 4.30 & 13.80 & 10.90 & 9.70 & 10.20 & 9.60 \\
\hline $\begin{array}{l}\text { Before } \\
\text { dialysis }\end{array}$ & 0.67 & 1.02 & 0.77 & 0.68 & 1.17 & 1.10 & 0.99 & 1.05 & 1.03 \\
\hline After dialysis & 0.51 & 0.52 & 0.51 & 0.49 & 0.50 & 0.48 & 0.51 & 0.48 & 0.46 \\
\hline $\begin{array}{l}\text { Mean } \pm \text { SEM } \\
\text { fall in 5-HMF }\end{array}$ & $0.16 \pm 0.08$ & $0.51 \pm 0.17$ & $0.26 \pm 0.11$ & $0.19 \pm 0.05$ & $0.67 \pm 0.15$ & $0.62 \pm 0.14$ & $0.48 \pm 0.17$ & $0.56 \pm 0.10$ & $0.57 \pm 0.12$ \\
\hline$p$ & $<0.001$ & $<0.001$ & $<0.001$ & $<0.001$ & $<0.001$ & $<0.001$ & $<0.001$ & $<0.001$ & $<0.001$ \\
\hline \multicolumn{10}{|l|}{ Diabetic subjects } \\
\hline $\begin{array}{l}\text { Blood glucose } \\
(\mathrm{mmol} / \mathrm{l})\end{array}$ & 8.10 & 15.40 & 18.70 & 8.60 & 20.40 & 19.70 & 20.10 & 20.00 & 20.00 \\
\hline $\begin{array}{l}\text { Before } \\
\text { dialysis }\end{array}$ & 1.20 & 1.44 & 1.62 & 1.18 & 1.61 & 1.62 & 1.61 & 1.63 & 1.60 \\
\hline After dialysis & 0.94 & 0.95 & 0.93 & 0.95 & 0.96 & 0.94 & 0.96 & 0.92 & 0.94 \\
\hline $\begin{array}{l}\text { Mean } \pm \text { SEM } \\
\text { fall in 5-HMF }\end{array}$ & $0.25 \pm 0.16$ & $0.49 \pm 0.22$ & $0.70 \pm 0.25$ & $0.23 \pm 0.17$ & $0.65 \pm 0.39$ & $0.66 \pm 0.41$ & $0.56 \pm 0.26$ & $0.71 \pm 0.30$ & $0.66 \pm 0.27$ \\
\hline$p$ & $<0.001$ & $<0.001$ & $<0.001$ & $<0.005$ & $<0.001$ & $<0.001$ & $<0.001$ & $<0.001$ & $<0.001$ \\
\hline
\end{tabular}

be partially related to a deglycosylation of the unstable aldiminic adduct, which, as also seen in the synthesis of $\mathrm{HbA}_{1}(1)$, can be formed in vivo, thus constituting a reversible step in the non-enzymatic glycosylation of serum proteins. This observation is also in agreement with the results of Yue et al. [5] who studied glycosylated serum proteins in vitro and showed that during dialysis, glucose slowly dissociates from proteins: after $24 \mathrm{~h}$, only $72 \%$ of glucose remained bound to the proteins.

The demonstration that, after serum dialysis, the 5-HMF assay does not undergo modifications during the various phases of experimental hyperglycaemia, shows that glycosylated serum proteins are not influenced either by transitory hyperglycaemic peaks or by high plasma glucose concentrations lasting for $5 \mathrm{~h}$. Therefore, it can be concluded that glycosylated serum protein levels are correlated with carbohydrate intolerance although, as determined by the thiobarbituric acid reaction test, they reflect the molecular alterations which can occur in serum proteins in response to increases in blood glucose levels lasting for more than $5 \mathrm{~h}$.

Yours sincerely,

G. Gragnoli, I. Tanganelli, A. M. Signorini, P. Tarli and C. Paoli

\section{References}

1. Svendsen PA, Christiansen JS, Søegaard V, Welinder BS, Nerup J (1980) Rapid changes in chromatographically determined haemoglobin $A_{1 c}$ induced by short-term changes in glucose concentration. Diabetologia 19:130-136
2. Bolli G, Cartechini MG, Compagnucci P, Santeusanio F, Massi Benedetti M, Calabrese G, Puxeddu A, Brunetti P(1980) Modification of glycosylated haemoglobin concentration during artificial endocrine pancreas treatment of diabetics. Evidence for a short-term effect on $\mathrm{HbA}_{1(\mathrm{a}+\mathrm{b}+\mathrm{c})}$ levels. Diabetologia 18: 125-130

3. McFarland KF, Catalano EW, Day JF, Thorpe SR, Baynes JW, (1979) Non-enzymatic glycosylation of serum proteins in diabetes mellitus. Diabetes 28:1011-1014

4. Kennedy AL, Mehl TD, Merimee TJ (1980) Non-Enzymatically glycosylated serum protein: spurious elevation due to free glucose in serum. Diabetes $29: 413-415$

5. Yue DK, Morris K, McLennan S, Turtle IR (1980) Glycosyation of plasma protein and its relation to glycosylated hemoglobin in diabetes. Diabetes 29: 296-300

6. Gabbay KH, Sosenko JM, Banuchi G, Mininsohn MJ, Fluckiger R (1979) Glycosylated hemoglobins: increased glycosylation of hemoglobin A in diabetic patients. Diabetes 28:337-340
Professor G. Gragnoli

Istituto di Clinica Medica Generale e

Terapia Medica

Università di Siena

Piazzetta della Selva 7

53100 Siena, Italy 